\title{
The Implementation of E-Learning into Language Learning: A Case of English Majors at Van Lang University
}

\author{
Minh Nguyen Thanh ${ }^{1, *}$ Phuc Dinh Tran Ngoc ${ }^{1}$ \\ ${ }^{1}$ Faculty of Foreign Languages, Van Lang University \\ "Corresponding author. Email: minh.nt@vlu.edu.vn
}

\begin{abstract}
In the context of the pandemic COVID-19, higher education worldwide faced the difficulty of isolation and lockdown, which affects the traditional face-to-face classrooms. However, due to the technological advance and the blooming of E-learning, many institutions had minimized the disease's consequences and created their way of teaching and learning. In Vietnam, Van Lang University (VLU) is considered a pioneer in converting from face-to-face classrooms to virtual ones to adjust to the current situation. Nevertheless, the issue of how VLU learners perceived this conversion was not paid enough attention. Hence, this paper aims at investigating the factors affecting the implementation of E-learning at Van Lang University in light of students' perspectives. Specifically, more than 300 English majors were involved in this survey study. All the students' responses were analyzed and synthesized using ELAM (E-learning Acceptance Model) and EFA - Exploratory Factor Analysis. The findings prevailed primary factors affecting students' perspective towards E-learning. Also, some suggestions were made to enhance the current situation.
\end{abstract}

Keywords: E-learning, Language Teaching, English Majors, Van lang University.

\section{INTRODUCTION}

These days, with the advance of information technology and communication, every facet of society has changed significantly. Aberta Education (2011) [1] has called out the $21^{\text {st }}$ skills, including digital and technology skills. Following this current trend, education over the world has adopted ITC and created a new form of learning - E-learning. Due to its benefits, E-learning has been using widely over the world (Hao, 2013; Babu \& Reddy; 2015)[2] [3]. In Vietnam, E-learning has been applied and developed since the 1990s, but the number of courses and learners was minimal (Hiep \& Tien, 2020) [4].

However, the outbreak of COVID-19 has forced many schools and institutes worldwide to use E-learning as the primary tool for teaching and learning (Dhawan, 2020) [5]. Vietnam has also experienced a considerable number of higher institutions and schools shifting from offline to online classes. In such a sudden situation, along with the "new normal" in living with the pandemic, there was a need to discover how well students have accepted the new form of learning. Therefore, this research was essential as it provided feedback for the stakeholder to reflect how E-learning had affected students' perspectives and whether they would have intentions in using it in the future.

\section{LITERATURE REVIEW}

\subsection{E-learning in Higher Education}

\subsubsection{Definition of E-learning}

According to Epignosis LLC (2014) [6], E-learning was first used in 1999 at a seminar related to CBT (computer-based training) program. Since then, other terms have been in existence to pursue accurate descriptions, such as online learning or virtual learning. Specifically, Badrul (2010) [7] has defined E-learning as an approach in which the learners are the center of 
teaching and learning activities with well-designed interactions facilitated by technological advances. It creates ultimate opportunities for learning at any time and anywhere. Also, Sangrà, Vlachopoulos, and Cabrera (2016) [8] identified four extents to define E-learning: (1) "Technology-driven" (the use of technology to assist training/teaching program) (2) "Delivery-systemoriented" (the use of electronic means to deliver educational program), (3) "Communication-oriented" (the use of electronic materials and online interaction between teachers and students), and (4) "Educationalparadigm-oriented" (the use of ICT (information and communication technology) to facilitate student learning.

In general, E-learning could be defined as the learning happening with the assistance of ICT to create a studentcentered and virtually meaningful interaction to tackle the limitation of traditional face-to-face learning.

\subsubsection{E-learning in Higher Education}

E-learning has been applied in higher education for a long time due to its benefits. Beatrice, (2011) [9] considered E-learning as an alternative for learners having difficulties attending conventional classrooms, such as long distances, working learners, or learners facing real-time communication problems. Moreover, Epignosis LLC (2014) [6] lists out the significant advantages: (1) Bound-free and Limitation-free, (2) Enjoyable, (3) Cost-saving, and (4) Adaptive to the new context.

In the outbreak of COVID-19, E-learning is the current trend in "keeping the classroom going on." Sathishkumar, Radha, Saravanakumar, and Mahalakshmi (2020) [10] state that E-learning becomes more popular and could help students develop self-studying skills in universities. Meanwhile, Michael (2020) [11] has strongly predicted that in the post-era of the pandemic, Elearning's normalization could be extended more.

In the Vietnamese context, (Hiep \& Tien, 2020) [4] investigate the past of E-learning in Vietnam and universities' as well as the government's responses to the COVID-19. They point out that although Vietnam has made a great effort in developing E-learning since the 1990s, the available E-learning courses and the participants in these courses were presented in a small number. Nevertheless, the sudden COVID-19 has turned everything around. Due to the command of suspending school and not stopping the school from the Ministry of Education and Training (MOET), more than 100 universities and institutions converted from traditional classrooms to online classrooms. Significantly, $70 \%$ of these were in the private sector (MOET, 2020) [12]. More than that, the paper emphasizes that E-learning was received official recognition from the government, and the "new normal" with E-learning would continue to spread out.
All in all, many universities and institutions nowadays have employed e-learning for such a long time, and the current situation has created a push for E-learning to become more popular.

\subsection{Factors affecting using E-learning of students}

The factors influencing students' E-learning use are complicated and hard to cover in the literature. Stewart, Hong, and Strudler (2004) [13] suggest some aspects related to the Web-based courses, such as the Web's appearance, classroom conduction procedures, technological knowledge, and classroom interactions. Yixin (2005) [14] indicates some other factors, including enjoyment, usefulness, anxiety, and self-efficacy. More recently, Osman, Wahid, and Zakria (2018) [15] have illustrated six factors that have impacts on using Elearning, consisting of service, system, content, instructors, and supports). These authors also suggest that if the stakeholders want their students to engage more and make the best use of E-learning, these factors need to be paid more attention. All in all, most papers have focused on three main dimensions: (1) technology, (2) teachers' perspective, and (3) students' perspectives.

\subsection{Studies on E-learning implementation}

\subsubsection{Technology Acceptant Model (TAM)}

David (1989) [16] has applied this model to identifying people's attitudes and behaviors towards using technology. In short, this model proposes two key aspects: (1) PU (Performance Expectancy) and (2) PEOU (effort expectancy). The former refers to the students' ideas that E-learning helps them study better, while the latter indicates the thinking that the implementation of Elearning needs less mental effort. The model has been applied in many studies. For instance, Ya-Ching (2016) [17] has investigated more on the extended factors besides the technological ones. He assumes that social elements should be taken into consideration. Ali, Kate, and Xiaohui (2013) [18] have confirmed in their paper the acceptance of using E-learning of students depends on the feeling of its benefits and the ease in using technology. This model brought about the knowledge of technological factors affecting the students' accepting Elearning. However, the social aspects are not given enough attention.

\subsubsection{Critical Success Factor Models (CSFs)}

These models have been applied in the university environment due to their coverage in four main areas: (1) the teachers, (2) students, (3) IT (information technology), and (4) the assistance from the universities. These findings were confirmed by the study of Selim (2007) [19]. The models suggest that the critical factors are E-learning attitudes, the control of technology, and the teaching styles in terms of teachers' perspectives. 
Meanwhile, in light of students', the central elements are computer literacy, student interactions, content, and the design of the course itself. The model added to the previous one the teachers and students' perspectives towards E-learning.

\subsubsection{E-learning Acceptance Model (ELAM)}

Since these two models tackle different factors in accepting E-learning but could not cover all the factors as a whole, the model called E-learning Acceptance Models (ELAM) had been proposed by Khan and Iyer (2009) [20]. In a nutshell, the model focuses on investigating the intention of suing E-learning via behavioral analysis. Four dimensions have been identified, including (1) Performance Expectancy, (2) Effort Expectancy, (3) Social Influence, and (4) Facilitating Conditions. The first factor is the exploration of usefulness, interactivity, and flexibility. In contrast, the second one explores the attitudes towards ease in learning, using E-learning, and self-efficacy. The others refer to society's external factors and the support from all the stakeholders, respectively. Many authors also employed this model. Recently, Teo (2010) [21] has conducted a study to validate the suggested framework from ELAM. The author concludes that ELAM had the most suitable design for the implementation, compared to others.

Figure 1. E-learning Acceptance Models (ELAM) (Khan, 2009)

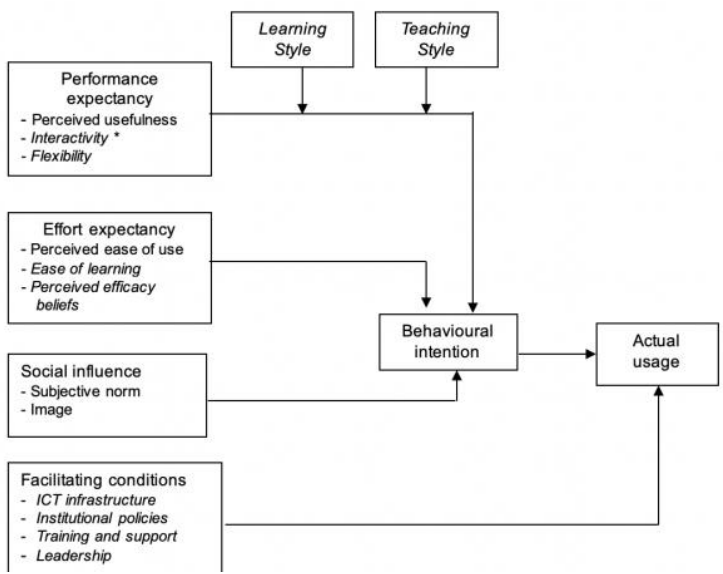

Therefore, this model was employed to analyze Elearning's intention from the students' perspectives. However, the researcher could not cover the study's Facilitating condition factors due to the limited time and effort.

\subsection{Research Aim and Research Question}

This study aimed at identifying the factors affecting students in using E-learning of English majors at Van Lang University in light of using ELAM models. Hence, the research question was:

What factors affect the English majors in using Elearning at Van Lang University?

\section{METHODOLOGY}

\subsection{Setting and Participants}

The study took place at the Faculty of Foreign Languages at Van Lang University. Briefly, the Faculty has about 2500 students with full-time training in four academic years. There are five minors for English majors, consisting of Teaching English, Business English, English for Tourism, English for Translation and Interpretation, and Chinese-English for Business. The students' significant demographic feature is that the number of female students overweighs that of male students. What is more, in the context of COVID-19, the Faculty followed the school's command and instructions to let the students participate in a $100 \%$ online course if they wished to. As a result, about 2000 students decided to take all the subjects online.

From the 2000 students participating in the online course, about 352 students were chosen continently to be the participants according to the Slovin's formula:

$$
\mathrm{n}=\mathrm{N} /\left[1+\mathrm{N}(\mathrm{e})^{2}\right]
$$

in which: $\mathrm{n}$ : Participants Needed

$$
\begin{aligned}
& \mathrm{N} \text { : Number of Population } \\
& \mathrm{e} \text { : Error Tolerance } \\
& \text { (in this case e }=0.05 \text { ) }
\end{aligned}
$$

\subsection{Research Design}

The study employed the quantitative approach in research. According to Fraenkel, Wallen, and Hyun, (2012) [22], and John (2018) [23], quantitative methodology aims at finding a defined problem by using statistical analysis and comparing the result with the literature. The result would be unbiased, and the variable could be the participants' attributes such as perspectives, behaviors or attitudes, etc. What is more, the survey study was the design of the research. Francis (2017) [24] states that a survey study is to identify common opinions on a specific topic. As a result, the quantitative survey design was suitable for the research.

\subsection{Research Instruments}

The main research instrument of the study was questionnaires. Fraenkel, Wallen, and Hyun (2012) [22] confirm that questionnaires have an advantage in collecting "big information" in such a short amount of time.

The study's questionnaire consisted of 30 statements covering three dimensions designed based on the ELAM model and the study of Anh (2015) [25]. The constructs of the questionnaire were listed in the following table: 
Table 1. The constructs covered in the questionnaire.

\begin{tabular}{|c|c|c|}
\hline Constructs & Statements & Code \\
\hline \multirow{14}{*}{$\begin{array}{l}\text { Performance } \\
\text { expectancy }\end{array}$} & 1. Using E-learning helps me study different subjects. & P1 \\
\hline & 2. Using E-learning increases my chance of getting a high score. & $\mathrm{P} 2$ \\
\hline & 3. Using E-learning helps me do my tasks more quickly. & $\mathrm{P} 3$ \\
\hline & 4. I could recognize the benefits of E-learning to my study. & $\mathrm{P} 4$ \\
\hline & $\begin{array}{l}\text { 5. Using E-learning could increase the number of subjects that I } \\
\text { could learn every day. }\end{array}$ & P5 \\
\hline & 6. Using E-learning increases my productivity in learning. & P6 \\
\hline & 7. Using E-learning free me from my workload at school. & $\mathrm{P} 7$ \\
\hline & $\begin{array}{l}\text { 8. Using E-learning helps me interact with the teachers and have } \\
\text { solutions to my problem in time. }\end{array}$ & P8 \\
\hline & $\begin{array}{l}\text { 9. Using E-learning helps me refer to many online resources such as } \\
\text { Wikipedia, search engine, etc. }\end{array}$ & P9 \\
\hline & $\begin{array}{l}\text { 10. Using E-learning helps me interact with my friends and work } \\
\text { together. }\end{array}$ & P10 \\
\hline & $\begin{array}{l}\text { 11. Using E-learning allows me to choose the lesson in term of my } \\
\text { interest. }\end{array}$ & P11 \\
\hline & 12. E-learning allows me to study in my comfort zones. & P12 \\
\hline & $\begin{array}{l}\text { 13. E-learning provides me with a chance to study everywhere and } \\
\text { every time. }\end{array}$ & P13 \\
\hline & 14. E-learning allows me to personalize my study. & P14 \\
\hline \multirow{8}{*}{$\begin{array}{l}\text { Effort } \\
\text { expectancy }\end{array}$} & 15. Learning how to use E-learning is easy for me. & E1 \\
\hline & 16. I think that using E-learning to do what I want is easy. & E2 \\
\hline & 17. Fluently using E-learning is easy for me. & E3 \\
\hline & 18. E-learning is easy to use. & E4 \\
\hline & 19. The interaction of me to E-learning is clear and understandable. & E5 \\
\hline & 20. Using E-learning requires intellectual efforts. & E6 \\
\hline & 21. I think I have the essential skills to use E-learning. & E7 \\
\hline & 22. Most of my teachers have experience in using E-learning. & E8 \\
\hline \multirow[t]{5}{*}{$\begin{array}{l}\text { Social } \\
\text { Influences }\end{array}$} & $\begin{array}{l}\text { 23. Most people (teacher, school stuff, etc.) around me want me to } \\
\text { use E-learning. }\end{array}$ & S1 \\
\hline & $\begin{array}{l}\text { 24. Most people who are important to me want me to use E-learning } \\
\text { as much as possible. }\end{array}$ & S2 \\
\hline & $\begin{array}{l}\text { 25. In my school, students with high skills in E-learning are more } \\
\text { reliable than the others. }\end{array}$ & S3 \\
\hline & $\begin{array}{l}\text { 26. Using E-learning in my school is considered as a factor to } \\
\text { determine who is excellent. }\end{array}$ & S4 \\
\hline & 27. E-learning could help me gain my reputation. & S5 \\
\hline
\end{tabular}

The students would then base on the statement and chose the suitable scale from 1 to 5 , which was identical with the range from totally agree, agree, undecided, disagree, and totally disagree. Along with these constructs, the researcher also asked the students about their intentions in using E-learning. There were two questions related to this construct: (I1) I will use Elearning in the next semester, and (I2) I plan to use Elearning in the following semester.

\subsection{Data collection procedures}

The questionnaires were delivered to all the students via online and offline forms to collect enough data for the research. Besides, the questionnaires were given after all the students had finished their online course due to the lockdown of COVID-19.

\subsection{Data analysis procedures}

Exploratory Factor Analysis (EFA) was used in the study to narrow down and summarize the raw data. This method was essential in gathering all the variables and identifying their relationship. Firstly, the method of Principal Axis Factoring was used with Promax rotation in order to summarize all the variables and gather variables into larger categories. Specifically, the loading factor of the variables was paid attention to with the maximum level $>=0.5$. What is more, in each item, the difference between the maximum factor loading and any factor loading should be $>=0.3$. Then, the total Average Variance Extracted was $>50 \%$, KMO was $>=0.5$, and Sig was $<0.05$.

\subsection{Reliability and Validity}

In order to ensure the reliability of the study, the research instrument was designed based on the ELAM model. Additionally, the items questions were adapted from the study of Anh (2015) [25]. As listed above, the research instrument was created based on the conceptual framework and the previous research in terms of validity. In designing the questionnaire, the researcher strictly followed the constructs covered in the model and grouped all the items in terms of the constructs. Another thing to point out is that the sampling method is a convenient sampling. However, the researcher delivered the questionnaire to the students experiencing the Elearning during the pandemic only. Therefore, they would use their own experiences in responding to the question items.

\section{FINDINGS AND DISCUSSION}

\subsection{Performance Expectancy, Effort Expectancy, and Social Influences}

The data were analyzed by using SPSS with the EFA. Specifically, three constructs were covered, including Performance Expectancy, Effort Expectancy, and Social Influences. After using EFA, some variables did not meet the loading factor's standard $(>=0.5)$. Therefore, they were eliminated to find the group of suitable elements, including E6, P9, P7, E2, P14, E3, P13, and P5. Then, the result of EFA was presented in the following table:

Table 2. The result of KMO and Bartlett's test

\begin{tabular}{lrr}
\hline KMO & & 0.807 \\
\hline HBartlett & Approx. Chi-Square & 2549.365 \\
& df & 171 \\
& Sig. & 0.000 \\
\hline
\end{tabular}

It is easy to find that the Average Variance Extracted was about $55.74 \%$ (>50\%), KMO was > 0.5, and Sig. < 0.05 . Therefore, the result of the EFA was meaningful. 
Table 3. The result of EFA

\begin{tabular}{|c|c|c|c|c|c|c|}
\hline \multirow{2}{*}{ Variables } & \multicolumn{5}{|c|}{ FACTORS } & \multirow[b]{2}{*}{6} \\
\hline & 1 & 2 & 3 & 4 & 5 & \\
\hline S3 & 0.827 & & & & & \\
\hline S4 & 0.803 & & & & & \\
\hline S2 & 0.667 & & & & & \\
\hline S5 & 0.638 & & & & & \\
\hline S1 & 0.528 & & & & & \\
\hline P3 & & 0.681 & & & & \\
\hline P2 & & 0.660 & & & & \\
\hline P1 & & 0.620 & & & & \\
\hline P4 & & 0.595 & & & & \\
\hline P6 & & 0.501 & & & & \\
\hline E4 & & & 0.977 & & & \\
\hline E3 & & & 0.691 & & & \\
\hline E5 & & & 0.653 & & & \\
\hline E7 & & & & 0.773 & & \\
\hline E8 & & & & 0.750 & & \\
\hline P10 & & & & & 0.793 & \\
\hline P8 & & & & & 0.762 & \\
\hline P12 & & & & & & 0.888 \\
\hline P11 & & & & & & 0.580 \\
\hline Eigenvalues & 5.190 & 2.454 & 1.613 & 1.434 & 1.216 & 1.177 \\
\hline $\begin{array}{l}\text { Average Variance } \\
\text { Extracted (\%) }\end{array}$ & & & & & & 55.744 \\
\hline
\end{tabular}

From table 3, all of the variables were set into six groups: (1) Perceived usefulness (S3, S4, S2, S5, S1), (2) Interactivity (P3, P2, P1, P4, P6), (3) Flexibility (E3, E4, E5), (4) Ease of Learning (E7, E8), (5) Perceived efficacy belief (P10, P8), and (6) Social Influences (P12, P11).

\subsection{The intentions of using E-learning}

The data related to intention in using E-learning of the students were analyzed using Min, Max, and Mean. The result was listed in the below table:

Table 4. Students' intention in using E-learning.

\begin{tabular}{|c|c|c|c|c|}
\hline & N & Minimum & Maximum & Mean \\
\hline I1 & 353 & 1,00 & 5,00 & 3,5297 \\
\hline I2 & 353 & 1,00 & 5,00 & 3,4929 \\
\hline
\end{tabular}

In short, the students' responses to the last two statements were about 3.5 in terms of the mean.

\subsection{Discussion}

The findings concluded that the factors affecting the English majors using E-learning at Van Lang University were the Usefulness of E-learning, the Interaction Features, the Flexibility Features, the Ease of Using, the Effectiveness of E-learning, and Social Influences. These factors were in line with each index of the ELAM model's components. However, there were differences, i.e., some factors had more significant effects than the others. These factors are also identical to the factors suggested by Yixin (2005) [14] and Osman, Wahid, and Zakria (2018) [15].

Also, from the items related to using E-learning, the mean was around 3.5, which was not high (between undecided and agree). Therefore, it could be readable that students were not ready for using E-learning further.

\section{CONCLUSION AND IMPLICATION}

The study investigated the factors affecting Englishmajored students in using E-learning at Van Lang University. This survey study adapted the ELAM model and used EFA (Exploratory Factor Analyses) to determine which factors should be considered in the current situation. After analyzing all the data, the research identified six factors, including (1) Perceived usefulness, (2) Interactivity, (3) Flexibility, (4) Ease of Learning, Perceived efficacy belief, and (6) Social Influences. The research finding suggested that despite being fully experienced in using E-learning, the students were unsure whether they would use E-learning in the future. To tackle this problem, the stakeholder should pay more attention to the research factors. To be more specific, students should be equipped with enough computer literacy skills. Then, the online interactions and the lesson's content should be suitable and fixable to all their needs.

Despite the essential findings, the research remained some limitations. Firstly, it could be better if the researcher used random sampling to increase the research's generalizability. Second, the result of the factors affecting E-learning and the intention could be analyzed more by checking the relationship between them. Additionally, the ELAM model was not adapted fully in the research. Lastly, the teachers' opinions should be considered to have more information on both sides, teacher and students.

\section{AUTHORS' CONTRIBUTIONS}

Minh Nguyen Thanh is a lecturer at Van Lang University, Ho Chi Minh, Vietnam. He has attended some conferences in the field of language learning and teaching. His recent papers were "Applying Blended Learning into Teaching English at Van Lang University" and "Constructive Alignment in Teaching English at Tertiary Level: An Insight into an AUN-Designed Course At Van Lang University" published in the proceeding of ICOE2019 and OPENTESOL2020 (hold by HCMC Open University). He has participated in teaching both English and Non-English majors. His interests are Curriculum Development and Language Assessment.

Phuc Dinh Tran Ngoc is a lecturer at Van Lang University, Ho Chi Minh, Vietnam. She has worked in teaching English for both English and Non-English majors for about 10 years. Her research interests are teaching methodology and teacher education. 


\section{ACKNOWLEDGMENTS}

Part of this paper was supported by Faculty of Foreign Languages, Van Lang University.

\section{REFERENCES}

[1] Aberta Education, Framework of Student Learning, Canada, 2011.

[2] Y. H. Hao, New World, New Learning: Trends and Issues of E-Learning, Procedia - Social and Behavioral Sciences, 77, 429-442. 10.1016/j.sbspro.2013.03.098, 2013.

[3] N. Babu, Dr. Reddy, Challenges and Opportunity of E-Learning in Developed and Developing Countries-A Review, International Journal of Emerging Research in Management and Technology, 4, 2278-9359, 2015.

[4] P. H. Hiep, H. T. H. Tien, Toward a 'new normal' with e-learning in Vietnamese higher education during the post COVID-19 pandemic, Higher Education Research \& Development, 39:7, 13271331, DOI: 10.1080/07294360.2020.1823945, 2020.

[5] S. Dhawan, Online Learning: A Panacea in the Time of COVID-19 Crisis, Journal of Educational Technology Systems, 49(1), 5-22, https://doi.org/10.1177/0047239520934018, 2020.

[6] Epignosis LLC, E-learning: Concepts, Trends and Application, California, 2014

[7] K. H. Badruh, The Global e-Learning Framework, Khan Academy, 2010.

[8] A. Sangrà, D. Vlachopoulos, N. Cabrera, Building an inclusive definition of e-learning: An approach to the conceptual framework, Int. Rev. Res. Open Distrib. Learn, 13, 145-159, 2012.

[9] G. Beatrice, E-learning methodologies: A guide for designing and developing e-learning courses, FAO, 2011.

[10] V. Sathishkumar, R. Radha, Ar. Saravanakumar, K. Mahalakshmi, E-Learning during Lockdown of Covid-19 Pandemic: A Global Perspective, International Journal of Control and Automation, 13, 1088-1099, 2020.

[11] M. Michael, COVID-19 and emergency eLearning: Consequences of the securitization of higher education for post-pandemic pedagogy, Contemporary Security Policy, 41, 1-14, 10.1080/13523260.2020.1761749, 2020.
[12] MOET, The information and communications going along with education and training in the preventing Covid-19, Publication No. 02/04/2020, 2020.

[13] I. Stewart, E. Hong, N. Strudler, Development and validation of an instrument for student evaluation of the quality of web-based instruction, American Journal of Distance Education, 18(3), 131-150, 2004.

[14] Z. Yixin, Development and validation of an internet use attitude scale, Computers \& Education, 49, 243-253, 2005.

[15] M. A. Osman, W. Abdul, A. Khalid, A. Zakaria, Assessment of Factors Affecting E-learning: Preliminary Investigation, 2018.

[16] F. D. Davis, Perceived usefulness perceived ease of use and user acceptance of information technology, MIS Quart., 13, 3, 319-340, 1989.

[17] L. Ya-Ching, An empirical investigation into factors influencing the adoption of an e-learning system", Online Information Review, 30, 5, 517 - 541, 2016.

[18] A. Tarhini, Ali, K. Hone, X. Liu, Factors Affecting Students' Acceptance of e-Learning Environments in Developing Countries: A Structural Equation Modeling Approach, International Journal of Information and Education Technology, 3. 54-59, 10.7763/IJIET.2013.V3.233, 2013.

[19] H. M. Selim, Critical success factors for e-learning acceptance: Confirmatory factor models, Computers \& Education, 49(2), 396-413. doi:10.1016/j.compedu.2005.09.004, 2007.

[20] F. Khan, S. Iyer, Elam: A model for acceptance and use of e-learning by teachers and students, Proceedings of the International Conference on eLearning, ICEL, 2009, 475-485, 2009.

[21] T. Teo, Development and validation of the Elearning Acceptance Measure (ElAM), The Internet and Higher Education, 13(3), 148-152. doi:10.1016/j.iheduc.2010.02.001, 2010.

[22] J. R. Fraenkel, N. E. Wallen, H. H. Hyun, How to design and evaluate research in education, New York: McGraw-Hill Humanities/Social Sciences/Languages, 2012.

[23] Cr. W. John, Educational Research: Planning, Conducting, And Evaluating Quantitative And Qualitative Research, 6 ${ }^{\text {th }}$, Pearson, 2018.

[24] L. Francis, Handbook of eHealth Evaluation: An Evidence-based Approach, University of Victoria, 2017.

[25] L. N. Q. Anh, Applying E-learning into Teaching and Learning at School of Economy, Hue University, 2015. 